\title{
Absorptive Capabilities and Competitive Advantage: The Linkage
}

\author{
Orlando Rua ${ }^{1 *}$ \\ 1 Porto Accounting and Business School, CEOS / CEI / ISCAP / P.Porto, UNIAG / APNOR, NECE / UBI Polytechnic Institute of Porto, \\ Rua Jaime Amorim Lopes, s/n, 4465-004 S. Mamade de Infesta, Portugal \\ * Corresponding author, e-mail: orua@iscap.ipp.pt
}

Received: 25 January 2018, Accepted: 03 March 2019, Published online: 07 August 2019

\begin{abstract}
The main goal of this study is to analyze the influence of absorptive capabilities on competitive advantage. Based on survey data from 247 Portuguese small and medium-sized enterprises (SMEs) findings suggest that:

1. Acquisition, assimilation and exploitation's absorptive capabilities are positively associated with cost leadership;

2. Transformation's absorptive capabilities are not positively associated with cost leadership;

3. Acquisition and transformation's absorptive capabilities are positively associated with differentiation; and

4. Assimilation and exploitation's absorptive capabilities are not positively associated with differentiation.
\end{abstract}

This study deepens our understanding and provides novel insights into strategic management literature, since it combines multiple factors and has obtained the importance of each construct in SMEs business competitive advantage. Moreover, this paper presents further evidences of the strategies that small firm managers should pursue and policy makers should promote.

Keywords

absorptive capabilities, competitive advantage, SMEs, Portuguese textile industry, PLS-SEM

\section{Introduction}

Resource-based scholars argue that resources form the basis of firm strategies (Barney, 1991) and intangible resources are more likely than tangible resources to produce a competitive advantage, since they are often rare and socially complex, thereby making them difficult to imitate (Hitt et al., 2001). Thus, intangible assets are considered strategic variables (Amit and Schoemaker, 1993) and can consequently create sustainable value. Firms with valuable, scarce, and nonsubstitutable resources can gain at least temporary advantages by using those resources to develop and implement product-market strategies (Hsu and Ziedonis, 2013).

The firms' success depends not only on its' resources and capabilities, but also the ability to adapt itself to the industry contingencies and markets in which operates. Firms may possess resources but must display dynamic capabilities otherwise shareholder value will be destroyed (Bowman and Ambrosini, 2003). It is in this context that emerges the Dynamic Capabilities View (DCV) (Amit and Schoemaker, 1993; Teece et al., 1997) to support the adjustment to environmental change. DCV is not divergent but rather an important stream of RBV to gain competitive advantage in increasingly demanding environments (Ambrosini and Bowman, 2009; Barreto, 2010; Eisenhardt and Martin, 2000; Wang and Ahmed, 2007). Monteiro et al. (2017) defend that in versatile markets, firms' capabilities should be dynamic and managers must display the ability to ensure consistency between business environment and strategy in order to continuously renew skills.

Our study is responsive to the call of Sousa et al. (2008) which suggests that, in the context of international markets, firms' survival and expansion, and consequent economic growth of many countries, is strongly dependent on a better understanding of the determinants that influence competitive advantage. In fact, the factors that set off SME growth (including exporting) are still in need of research (Stouraitis et al., 2017). So, the purpose of this paper is to broad the boundaries of entrepreneurship and strategic management literature and test the following hypotheses - does absorptive capabilities positively influence small business competitive advantage? 


\section{Theoretical framework}

\subsection{Absorptive capabilities}

In modern business environment with high turbulence, knowledge has been designated as a dominant source of competitive advantage. In order to survive certain pressures, companies need to recognize, assimilate and apply new external knowledge for commercial purposes (Jansen et al., 2005). This ability, known as absorptive capability (ACAP) (Cohen and Levinthal, 1990), emerges as an underlying theme in the organizational strategy research (Jansen et al., 2005).

Cohen and Levinthal (1990) presented a definition of ACAP most widely cited by academic research, as the firm's ability to identify, assimilate and exploit new knowledge. Thus, this ability access and use new external knowledge, regarded as an intangible asset, is critical to success and depends mainly on prior knowledge level, since it is this knowledge that will facilitate the identification and processing of new one. This prior knowledge not only includes the basic capabilities, such as shared language, but also recent technological and scientific data or learning skills. By analyzing this definition is found that absorptive capability of knowledge only three dimensions:

1. the ability to acquire external knowledge;

2. the ability to assimilate it inside; and

3. the ability to apply it.

Zahra and George (2002) divided ACAP in Potential Absorptive Capability (PACAP) and Realized Absorptive Capability (RACAP). PACAP reflects the firms' ability to acquire and assimilate knowledge that is vital for their activities. Knowledge identification, acquisition and assimilation is related to routines and processes that permit to analyze, process, interpret and understand external information. RACAP includes knowledge transformation and exploitation, where transformation is the ability to develop routines that facilitate the integration of newly acquired knowledge in existing one. Knowledge exploitation is a routine which enhances existing skills or creates new ones by incorporating acquired and transformed knowledge internally.

In order to cope and enhance each ACAP dimension, Jansen et al. (2005) argue that firms need to develop organizational mechanisms which enable them to synthesize and apply newly acquired knowledge. Thus, there are coordination mechanisms that increase the exchange of knowledge between sectors and hierarchies, like multitasking teams, participation in decision-making and job rotation. These mechanisms bring together different sources of expertise and increase lateral interaction between functional areas. System mechanisms are behavior programs that reduce established deviations, such as routines and formalization. Socialization mechanisms create a broad and tacit understanding of appropriate rules of action, contributing to a common code of communication.

\subsection{Competitive advantage}

The increased intensity of business competition has forced firms to adopt a non-traditional management techniques and tools. Maintaining competitive advantage is a dynamic and infinite activity (Hung et al., 2010).

How firms achieve and sustain competitive advantage? This is the fundamental question in the field of strategic management (Teece et al., 1997). Porter (1985) considers simply a matter of creating value for customers and doing it better than competition.

Porter's model to classify firm strategies remains the most commonly supported and acknowledged framework in strategic management literature (Allen et al., 2006). Porter (1985) proposed four competitive strategies:

1. broad cost leadership,

2. broad differentiation,

3. cost focus and

4. differentiation focus.

While cost leadership or differentiation is defined as dominant competitive strategies, focus is not a standalone strategy and "is not sufficient for above-average performance" (Porter, 1985: p. 15). Consequently, there is a tendency in the literature to recognize two main sources of competitive advantage:

1. cost leadership - reaching lower costs than competitors and

2. differentiation - creating more value for customers than the average firm (Lechner and Gudmundsson, 2014).

Furthermore, and according to Porter (1985), the two logics of differentiation and cost leadership are incompatible.

Hence, we can reduce the study of competitive strategy to differentiation and cost leadership, especially if the competitive strategy is related to other strategic elements of firm's behavior. Differentiation means to fulfil customers' needs in a unique way, based on speed, customer service and flexibility, which is consistent with innovative approaches and characteristics of entrepreneurial firms. Cost leadership requires 
substantial financial resources (to invest in tangible assets), is based on process innovation, learning curve benefits, economies of scale and standardization, and seems to be less appropriate for small firms, given the resource constraints (Lechner and Gudmundsson, 2014).

Sustainable competitive advantage represents firm's competitive maintenance on the long run, whose performance is above average, resisting the dynamic evolution of competition, consumers and industry (e.g. Amit and Schoemaker, 1993; Peteraf, 1993; Porter, 1985).

Teece et al. (1997: p. 516) defined dynamic capabilities as the "firm's ability to integrate, build, and reconfigure internal and external competences to address rapidly changing environments". Dynamic capabilities thus reflect firms' ability to achieve new and innovative forms of competitive advantage. ACAP is a dynamic capability found in organizational processes that enables firms to reconfigure their core resources, react to environmental dynamics and build competitive advantage (Zahra and George, 2002).

Thus, this study tests the following working hypotheses:

- H1a: Acquisition's absorptive capabilities are positively associated with cost leadership.

- $H 1 b$ : Acquisition's absorptive capabilities are positively associated with differentiation.

- H2a: Assimilation's absorptive capabilities are positively associated with cost leadership.

- $H 2 b$ : Assimilation's absorptive capabilities are positively associated with differentiation.

- H3a: Exploitation's absorptive capabilities are positively associated with cost leadership.

- $H 3 b$ : Exploitation's absorptive capabilities are positively associated with differentiation.

- H4a: Transformation's absorptive capabilities are positively associated with cost leadership.

- H4b: Transformation's absorptive capabilities are positively associated with differentiation.

\section{Method}

\subsection{Sample and data collection}

The population of this empirical study has been drawn from Portuguese textile industry firms. Questionnaires were used as primary data sources and were carried out over the period of February 16 to April 30, 2016. The identification of companies was done through the Portugal's Textile Association (Associação Têxtil e Vestuário de Portugal - ATP) database. So, in this study we use a non-probabilistic and convenient sampling (ATP, 2014).
A total of 247 complete and validated questionnaires accounting for $25 \%$ per cent of the population were obtained. This response rate is considered quite satisfactory, given that the average of top management survey response rates are in the range of 15\%-20\% (Menon et al., 1999).

\subsection{Statistical analysis}

We used PLS-SEM path modelling to test our hypothesis, specifically the software SmartPLS 3.0 (Hair et al., 2013; Sarstedt et al., 2014). We believe that the PLS-SEM path modelling is best suited to estimate our research model since:

1. this study focuses on prediction and explanation of constructs variance (in our case 6);

2. our research model has a complex structure;

3. the relationship between entrepreneurial orientation, intangible resources, absorptive capabilities and export performance can be measured directly and indirectly via competitive advantage;

4. this study uses first and second-order reflective constructs; and

5. the sample $(n=247)$ is somewhat small.

\subsection{Measures}

This study uses well-validated scales from previous studies to operationalize the key constructs and adapted them to the particular context of our empirical setting.

Independent variables - According to Zahra and George (2002), ACAP construct is divided in Potential Absorptive capabilities (PACAP) and Realized Absorptive capabilities (RACAP). To measure this construct we use Jansen et al. (2005) scale.

Dependent variable - Competitive strategy was measured through two dimensions, differentiation and cost leadership, using Morgan et al. (2004) scale.

\section{Results}

\subsection{Non-response bias and common method bias}

In this study we performed a univariate test of significance ( $t$-test), to examine existing differences between respondents who answered our questionnaire quickly and those who did not. The results $(p<0.05)$ showed the absence of significant differences between the two groups of respondents. Hence, we can assure that our sample is free from non-response bias. The methods used to reduce the risk of common method-bias were several. In the survey design itself, already validated in previous investigations, short and concise items were used to reduce misunderstandings. A pre-test was conducted to a group of several university 
experts and business specialists. Similarly, following the recommendation of Podsakoff et al. (2003), a distribution of items of dependent and non-consecutive independent variables was used. Finally, before assessing the relationships between dependent and independent variables, Harman's single-factor test was performed. Unrotated factor analysis using the eigenvalue-greater-than-one criterion revealed six factors, the first explaining 17.0 percent of the variance. This suggests that common method bias is not a serious threat to the validity of our study.

Next, in order to analyze and interpret the PLS-SEM results, we will:

1. assess the measurement model; and

2. evaluate and test the structural model.

\subsection{Evaluation of measurement model}

Results from Table 1 show that the measurement model meets all general requirements. First, all reflective items have a load higher than 0.707 , which means that the reliability of individual indicators (loading ${ }^{2}$ ) are higher than 0.5 . Second, all composite reliability values and Cronbach's alpha values are higher than 0.70 , suggesting acceptable model reliability. Third, the average variance extracted (AVE) values of all constructs are higher than 0.50 , indicating an adequate convergent validity and implying that our set of indicators represent the same underlying construct (Hair et al., 2013).

Finally, regarding discriminant validity, this paper presents two necessary approaches:

1. the first approach suggests that the AVE should share more variance with its assigned indicators than with any other construct (Fornell-Larcker criterion) (Fornell and Larcker, 1981); and

2. the second approach suggests that no item should have a higher factor load with another construct than with the one which is assign to measure.

The results shown in Table 2 confirm the existence of discriminant validity in our study.

\subsection{Evaluation of structural model}

Once the measurement model is defined and validated in all its components, we will proceed and create the second order model, following previous research (e.g. Zahra and Garvis, 2000), where the latent variables of the measurement model behave as constructs' measurement variables. Specifically, Absorptive Capability (acquisition, assimilation, transformation and exploitation),
Competitive Advantage - Cost and Competitive Advantage - Differentiation (product and service).

In the following Tables 3 and 4, we present the results of reliability, convergent validity and discriminant validity corresponding to the second order model. All data confirm the strength of our model.

In order to analyze possible collinearity we used values from Variance Inflation Factor (VIF). The results show that VIF values for the independent variables are between 3.960 (Absorptive capabilities - Transformation) and 1.227 (Absorptive capabilities - Acquisition), indicating that, in line with Hair et al. (2013) or Diamantopoulos and Siguaw (2006), the results obtained are not negatively affected by collinearity.

Since the fundamental objective of our PLS-SEM technique is the prediction of Competitive Advantage, the quality of our theoretical model will be determined by measuring the strength of each path $(\beta)$, that is the relationship between Absorptive capabilities - Acquisition (ACAQ), Absorptive capabilities - Assimilation (ACAS), Absorptive capabilities - Exploitation (ACEX) and, Absorptive capabilities - Transformation (ACTR), in the predictability of the endogenous constructs Competitive Advantage - Cost (CAC) and Competitive Advantage Differentiation (CAD). Thus, to study our dependent variable, the value that we have to maximize is $R^{2}$. According to Hair et al. (2013) and Sarstedt et al. (2014), this coefficient measures the amount of construct variance that is explained by the model, where values of 0.5 are considered to be moderate and 0.25 weak. In our model, the mediators $R^{2}$ coefficient is 0.300 for CAD and 0.312 for CAC, so we can assert that these values are more than satisfactory.

Finally, and applying the non-parametric bootstrapping test, we evaluated the significance of mediation effects. The results show significance of coefficients shown in Fig. 1.

Results from Table 5 indicate that $\operatorname{ACAC}(\beta=0.361 ; p<$ $0.000), \operatorname{ACAS}(\beta=0.398 ; p<0.000)$ and $\operatorname{ACEX}(\beta=0.361$; $p<0.05$ ) have a positive and significant impact on CAC, supporting, respectively, $H 1 a, H 2 a$ and $H 3 a$. $H 4 a$ is not supported because ACTR $(\beta=-0.562 ; p<0.000)$.

On the other hand, two factors influence positively and significantly and positively CAD. Specifically, ACAC $(\beta=$ 0.258; $p<0.000)$ and ACTR $(\beta=0.270 ; p<0.05)$, which supports $H 1 b$ and $H 4 b$. The other two factor related with CAD does not supports $H 2 b$ and $H 3 b$ : ACAS $(\beta=-0.002$; $p=0.981)$ and $\operatorname{ACEX}(\beta=0.131 ; p=0.209)$.

These three relationships occur directly. 
Table 1 Measurement model

\begin{tabular}{|c|c|c|c|c|c|c|}
\hline First-order constructs & Items & Factor loading & Item loading & Cronbach's Alpha & Composite reliability & $\mathrm{AVE}$ \\
\hline \multicolumn{7}{|c|}{ ABSORPTIVE CAPABILITIES } \\
\hline & ACAQ1 & 0.729 & 0.531 & & & \\
\hline & ACAQ2 & 0.694 & 0.482 & & & \\
\hline \multirow[t]{4}{*}{ Acquisition* } & ACAQ3 & 0.830 & 0.689 & 0.782 & 0.850 & 0.532 \\
\hline & ACAQ4 & 0.687 & 0.472 & & & \\
\hline & ACAQ6 & 0.698 & 0.487 & & & \\
\hline & ACAS1 & 0.819 & 0.671 & & & \\
\hline \multirow[t]{4}{*}{ Assimilation } & ACAS2 & 0.932 & 0.869 & 0.847 & 0.907 & 0.766 \\
\hline & ACAS3 & 0.871 & 0.759 & & & \\
\hline & ACTR2 & 0.827 & 0.684 & & & \\
\hline & ACTR3 & 0.873 & 0.762 & & & \\
\hline \multirow[t]{5}{*}{ Transformation* } & ACTR4 & 0.795 & 0.632 & 0.874 & 0.908 & 0.665 \\
\hline & ACTR5 & 0.854 & 0.729 & & & \\
\hline & ACTR6 & 0.721 & 0.520 & & & \\
\hline & ACEX1 & 0.791 & 0.626 & & & \\
\hline & $\mathrm{ACEX} 2$ & 0.765 & 0.585 & & & \\
\hline \multirow[t]{4}{*}{ Exploitation } & ACEX3 & 0.866 & 0.750 & 0.897 & 0.922 & 0.663 \\
\hline & ACEX4 & 0.836 & 0.699 & & & \\
\hline & ACEX5 & 0.703 & 0.494 & & & \\
\hline & ACEX6 & 0.909 & 0.826 & & & \\
\hline \multicolumn{7}{|c|}{ COMPETITIVE ADVANTAGE } \\
\hline & $\mathrm{VCC} 1$ & 0.884 & 0.781 & & & \\
\hline \multirow[t]{4}{*}{ Cost } & $\mathrm{VCC} 2$ & 0.816 & 0.666 & 0.900 & 0.931 & 0.771 \\
\hline & $\mathrm{VCC} 3$ & 0.952 & 0.906 & & & \\
\hline & VCC4 & 0.855 & 0.731 & & & \\
\hline & VCP1 & 0.875 & 0.766 & & & \\
\hline \multirow[t]{4}{*}{ Product } & $\mathrm{VCP} 2$ & 0.903 & 0.815 & 0.924 & 0.946 & 0.814 \\
\hline & VCP3 & 0.929 & 0.863 & & & \\
\hline & VCP4 & 0.902 & 0.814 & & & \\
\hline & VCS1 & 0.863 & 0.745 & & & \\
\hline \multirow[t]{3}{*}{ Service } & $\mathrm{VCS} 2$ & 0.923 & 0.852 & 0.886 & 0.921 & 0.746 \\
\hline & VCS3 & 0.865 & 0.748 & & & \\
\hline & VCS4 & 0.799 & 0.638 & & & \\
\hline
\end{tabular}

* The variables ACAQ5 and ACTR1 corresponding, respectively, to Acquisition and Transformation were excluded from the measurement model due to low values. Accordingly, values lower than 0.7 generate a low correlation and threaten the reliability of the scale.

Table 2 Latent constructs correlation (Fornell-Larcker Criterion)

\begin{tabular}{|c|c|c|c|c|c|c|c|c|c|}
\hline & 1 & 2 & 3 & 4 & 5 & 6 & 7 & 8 & 9 \\
\hline 1. Acquisition & 0.730 & & & & & & & & \\
\hline 2. Assimilation & 0.307 & 0.875 & & & & & & & \\
\hline 3. Cost & 0.358 & 0.373 & 0.878 & & & & & & \\
\hline 4. Exploitation & 0.357 & 0.656 & 0.275 & 0.815 & & & & & \\
\hline 5. Innovativeness & 0.280 & 0.290 & 0.169 & 0.488 & 0.861 & & & & \\
\hline 6. Proactiveness & 0.028 & 0.256 & 0.114 & 0.316 & 0.303 & 0.876 & & & \\
\hline 7. Product & 0.407 & 0.259 & 0.303 & 0.488 & 0.465 & 0.148 & 0.902 & & \\
\hline 8. Service & 0.404 & 0.411 & 0.319 & 0.335 & 0.340 & 0.118 & 0.814 & 0.864 & \\
\hline 9. Transformation & 0.412 & 0.620 & 0.153 & 0.748 & 0.520 & 0.349 & 0.501 & 0.414 & 0.816 \\
\hline
\end{tabular}


Table 3 Convergence validity and reliability indexes of the secondorder model

\begin{tabular}{lccc}
\hline & Cronbach's Alpha & Composite Reliability & AVE \\
\hline ACAC & 0.776 & 0.839 & 0.471 \\
ACAS & 0.847 & 0.906 & 0.763 \\
ACEX & 0.897 & 0.921 & 0.661 \\
ACTR & 0.872 & 0.903 & 0.612 \\
CAD & 0.900 & 0.930 & 0.770 \\
CAC & 0.940 & 0.950 & 0.705 \\
\hline
\end{tabular}

Table 4 Discriminant validity index of the second-order model

\begin{tabular}{lcccccc}
\hline & 1 & 2 & 3 & 4 & 5 & 6 \\
\hline 1. ACAC & 0.686 & & & & & \\
2. ACAS & 0.337 & 0.873 & & & & \\
3. ACEX & 0.381 & 0.645 & 0.813 & & & \\
4. ACTR & 0.421 & 0.644 & 0.851 & 0.782 & & \\
5. CAD & 0.396 & 0.390 & 0.277 & 0.153 & 0.877 & \\
6. CAD & 0.421 & 0.343 & 0.458 & 0.489 & 0.335 & 0.840 \\
\hline
\end{tabular}

Table 5 Significant testing results of the structural model path coefficients

\begin{tabular}{|c|c|c|c|c|c|}
\hline & Original Sample $(O)$ & Sample Mean $(M)$ & Standard Deviation $(S T D E V)$ & $T$ Statistics $(|O / S T D E V|)$ & $P$ Values \\
\hline$H 1 a:$ ACAQ -> COST & 0.361 & 0.361 & 0.053 & 6.858 & 0.000 \\
\hline$H 1 b:$ ACAQ -> DIF & 0.258 & 0.259 & 0.058 & 4.462 & 0.000 \\
\hline$H 2 a:$ ACAS $->$ COST & 0.398 & 0.394 & 0.080 & 4.971 & 0.000 \\
\hline$H 2 b:$ ACAS -> DIF & -0.002 & 0.006 & 0.085 & 0.024 & 0.981 \\
\hline H3a: ACEX -> COST & 0.361 & 0.355 & 0.136 & 2.653 & 0.008 \\
\hline$H 3 b:$ ACEX -> DIF & 0.131 & 0.148 & 0.104 & 1.259 & 0.209 \\
\hline$H 4 a:$ ACTR $->$ COST & -0.562 & -0.550 & 0.109 & 5.173 & 0.000 \\
\hline$H 4 b:$ ACTR $->$ DIF & 0.270 & 0.264 & 0.089 & 3.032 & 0.003 \\
\hline
\end{tabular}

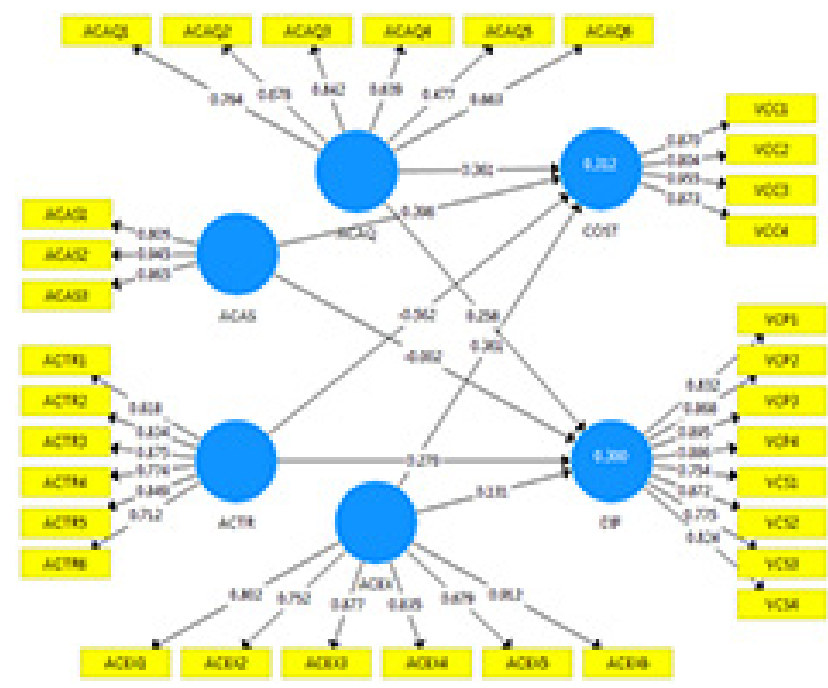

Fig. 1 Results of structural model

\section{Discussion and conclusions}

The main goal of this study is to analyze the influence of absorptive capabilities on competitive advantage.

Absorptive capabilities, generally, has a positive and significant impact on competitive advantage ( $H 1 a, H 1 b$, $H 2 a, H 3 a$ and $H 4 b$ supported). Teece et al. (1997) argue that, through dynamic capabilities, firms are able to develop, integrate, reconfigure and adapt their resources and capabilities to unpredictable markets and achieve competitive advantage. In this study it is demonstrated that our SMEs still do not include as it would be desired dynamic (absorptive) capabilities in the formulation of their competitive strategy, as suggested Zahra and George (2002). Hence, $H 2 b, H 3 b$ and $H 4 a$ were not supported.

Porter (1985) states that performance is enhanced by the design of a competitive strategy, combining strategic determinants previously defined (Morgan et al., 2004). Hence, competitive strategy matters for small firms.

Small traditional firms represent a very important part of the economic system in many European countries. Their significant contribution to the gross domestic product (GDP), national exports, and job creation, makes them an important policy target (Zucchella and Siano, 2014). In fact, and according to Portugal's Textile and Apparel Association (ATP), this industry in 2016 accounted for $20 \%$ of industrial employment, $9 \%$ of GDP and $10 \%$ of Portuguese industrial exports (ATP, 2014).

We can only speculate that the Portuguese textile industry faces considerable challenges, not only regarding the economic crisis in international markets, which restricts access to resources, but also concerning consumption patterns. Furthermore, international competitiveness does not allow SMEs to develop a competitive strategy based on differentiation, changing thus their business model paradigm. Indeed, mature industries are characterized by increased competition and price deflation due to overcapacity (Parrish et al., 2006). As reported by the ATP (2014), globalization pressures, such as textile 
trade liberalization, have considerably affected the industry. The textile sector is being subjected to strong pressures in a fast-changing business environment due to market volatility and strong competition world-wide. The key success factors of the industry are related primarily with cost (labor, energy, transport), but also with geographical location (flexibility, responsiveness, proximity service), knowledge (know-how, experience, technical expertise, research and development, networking) and recognition (tradition, brands, quality). Therefore, we acknowledge that the sector is developing strong differentiation factors. Firms in these mature markets must look for ways to stay competitive and develop strategies that enables them to differentiate themselves from other firms.

\subsection{Theoretical and practical implications}

Our study is responsive to the call of Sousa et al. (2008) which suggests that, in international market context, firms' survival and expansion, and consequent economic growth of many countries, is strongly dependent on a better understanding of the strategic determinants that influence competitive advantage. Moreover, our study confirms the importance of dynamic capabilities (e.g. Ambrosini and Bowman, 2009; Barreto, 2010; Eisenhardt and Martin, 2000; Wang and Ahmed, 2007).

We also highlight the contribution of this study to the theory of strategic management. It is known that strategy includes deliberate and emergent initiatives adopted by management, comprising resource and capabilities used to improve competitive advantage (Nag et al., 2007). In order to remain competitive, firms must assess which strategic determinants give them an advantage over their competitors. The findings are a contribution to clarify the influence of absorptive capabilities in small firms' competitive advantage.

Additionally, our findings provide guidance to business practitioners, since they indicate that absorptive capabilities are predictors of competitive strategies. The research has also shown the positive influences of generic strategies on firm's competitive advantage. So, for small firm managers, competitive strategy does matters and the development of one type of competitive advantage, alongside with firm's absorptive capabilities, is a major performance driver.

Thus, it is essential to understand and identify which absorptive capabilities are relevant to gain competitive advantage. Business owners must be able to systematically analyze the changes that arise in their target market(s) and to incorporate this knowledge into their processes, to identify the present and future needs and market trends, anticipate changes in demand and seek new business opportunities.

By building on the literature of strategic management, this study aims to support the strategic development of business management policies designed to increase firms' competitive advantage in foreign markets and add value to the current context of change.

\subsection{Research limitations}

While this research provides valuable insights into SMEs in the textile industry, the study is not without its limitations. First, the state of the economy might have affected our results. The low scores of willingness to take risks might be influenced by the current context of economic crisis. In fact, in a turbulent market, risk-taking is negatively associated to SME performance (Kraus et al., 2012) and is in fact related to firm failure (Lechner and Gudmundsson, 2014). Second, it would have been interesting to control our analysis. The fact that the research does not consider the effect of control variables such as age, location and target market of the respondents can be seen as a limitation. Third we used an online study to collect our data. While electronic data collection methods are becoming more common, strategies to encourage a greater response rate are lacking compared to other survey implementation methods. Finally, the fact that the sampling is non probabilistic and convenience is a limitation. Therefore we advise prudence in the generalization of results.

\subsection{Future lines of research}

Firstly, this study has been based on a mature sector, as is the textile sector in Portugal. The results obtained should be understood in this context. For this reason, new research could be done in more modern industries to test again the proposed relations. Second, given the irregular nature of business growth, a snapshot survey may not be able to capture strategy and performance variations over long periods of time. As such, further studies with a longitudinal perspective would be of added value to investigate why these differences persist. In other words, to find how and why some small exporters become highly successful while others, in the same industry, struggle to raise their export strengths. 


\section{References}

Allen, R. S., Helms, M. M., Takeda, M. B., White, C. S., White, C. (2006) "A Comparison of Competitive Strategies in Japan and the United States", SAM Advanced Management Journal, 71(1), pp. 24-34.

Ambrosini, V., Bowman, C. (2009) "What are dynamic capabilities and are they a useful construct in strategic management?", International Journal of Management Reviews, 11(1), pp. 29-49. https://doi.org/10.1111/j.1468-2370.2008.00251.x

Amit, R., Schoemaker, P. J. H. (1993) "Strategic Assets and Organizational Rent", Strategic Management Journal, 14(1), pp. 33-46. https://doi.org/10.1002/smj.4250140105

ATP (2014) "Plano Estratégico Têxtil 2020 - Projetar o Desenvolvimento da Fileira Têxtil e Vestuário até 2020" (2020 Textile Strategic Plan: Designing the development of textile and clothing row up to 2020), [online] Available at: http://www.atp.pt/fotos/editor2/Plano_ Estrategico_2020_ebook.pdf [Accessed: 15 September 2017] (in Portuguese)

Barney, J. (1991) "Firm Resources and Sustained Competitive Advantage", Journal of Management, 17(1), pp. 99-120. https://doi.org/10.1177/014920639101700108

Barreto, I. (2010) "Dynamic Capabilities: A Review of Past Research and an Agenda for the Future", Journal of Management, 36(1), pp. 256-280. https://doi.org/10.1177/0149206309350776

Bowman, C., Ambrosini, V. (2003) "How the Resource based and the Dynamic Capability Views of the Firm Inform Corporate-level Strategy", British Journal of Management, 14(4), pp. 289-303. https://doi.org/10.1111/j.1467-8551.2003.00380.x

Cohen, W. M., Levinthal, D. A. (1990) "Absorptive Capacity: A New Perspective on Learning and Innovation", Administrative Science Quarterly, Special Issue: Technology, Organization, and Innovation, 35(1), pp. 128-152.

https://doi.org/10.2307/2393553

Diamantopoulos, A., Siguaw, J. A. (2006) "Formative Versus Reflective Indicators in Organizational Measure Development: A Comparison and Empirical Illustration", British Journal of Management, 17(4), pp. 263-282.

https://doi.org/10.1111/j.1467-8551.2006.00500.x

Eisenhardt, K. M., Martin, J. A. (2000) "Dynamic capabilities: what are they?", Strategic Management Journal, 21(10-11), pp. 1105-1121. https://doi.org/10.1002/1097-0266(200010/11)21:10/11<1105::AIDSMJ133>3.0.CO;2-E

Fornell, C., Larcker, D. F. (1981) "Evaluating Structural Equation Models with Unobservable Variables and Measurement Error", Journal of Marketing Research, 18(1), pp. 39-50. https://doi.org/10.2307/3151312

Hair Jr., J. F., Hult, G. T. M., Ringle, C. M., Sarstedt, M. (2013) "A Primer on Partial Least Squares Structural Equation Modeling (PLS-SEM)", 2nd ed., SAGE Publications, Inc., Thousand Oaks, CA, USA.

Hitt, M. A., Bierman, L., Shimizu, K., Kochhar, R. (2001) "Direct and Moderating Effects of Human Capital on Strategy and Performance in Professional Service Firms: A Resource-Based Perspective", Academy of Management Journal, 44(1), pp. 13-28. https://doi.org/10.2307/3069334
Hsu, D. H., Ziedonis, R. H. (2013) "Resources as Dual Sources of Advantage: Implications for Valuing Entrepreneurial-Firm Patents", Strategic Management Journal, 34(7), pp. 761-781. https://doi.org/10.1002/smj.2037

Hung, R. Y. Y., Yang, B., Lien, B. Y.-H., McLean, G. N., Kuo, Y.-M. (2010) "Dynamic capability: Impact of process alignment and organizational learning culture on performance", Journal of World Business, 45(3), pp. 285-294. https://doi.org/10.1016/j.jwb.2009.09.003

Jansen, J. J. P., Van Den Bosch, F. A. J., Volberda, H. W. (2005) "Managing Potential and Realized Absorptive Capacity: How do Organizational Antecedents Matter?", Academy of Management Journal, 48(6), pp. 999-1015.

https://doi.org/10.5465/amj.2005.19573106

Lechner, C., Gudmundsson, S. V. (2014) "Entrepreneurial Orientation, Firm Strategy and Small Firm Performance", International Small Business Journal, 32(1), pp. 36-60. https://doi.org/10.1177/0266242612455034

Kraus, S., Rigtering, J. P. C., Hughes, M., Hosman, V. (2012) "Entrepreneurial orientation and the business performance of SMEs: a quantitative study from the Netherlands", Review of Managerial Science, 6(2), pp. 161-182. https://doi.org/10.1007/s11846-011-0062-9

Menon, A., Bharadwaj, S. G., Adidam, P. T., Edison, S. W. (1999) "Antecedents and Consequences of Marketing Strategy Making: A Model and a Test", Journal of Marketing, 63(2), pp. 18-40. https://doi.org/10.2307/1251943

Monteiro, A. P., Soares, A. M., Rua, O. L. (2017) "Linking intangible resources and export performance: The role of entrepreneurial orientation and dynamic capabilities", Baltic Journal of Management, 12(3), pp. 329-347. https://doi.org/10.1108/BJM-05-2016-0097

Morgan, N. A., Kaleka, A., Katsikeas, C. S. (2004) "Antecedents of Export Venture Performance: A Theoretical Model and Empirical Assessment", Journal of Marketing, 68(1), pp. 90-108. https://doi.org/10.1509/jmkg.68.1.90.24028

Nag, R., Hambrick, D. C., Chen, M.-J. (2007) "What is strategic management, really? Inductive derivation of a consensus definition of the field", Strategic Management Journal, 28(9), pp. 935-955. https://doi.org/10.1002/smj.615

Parrish, E. D., Cassill, N. L., Oxenham, W. (2006) "Niche market strategy for a mature marketplace", Marketing Intelligence \& Planning, 24(7), pp. 694-707. https://doi.org/10.1108/02634500610711860

Peteraf, M. A. (1993) "The Cornerstones of Competitive Advantage: A Resource-Based View”, Strategic Management Journal, 14(3), pp. 179-191. https://doi.org/10.1002/smj.4250140303

Podsakoff, P. M., MacKenzie, S. B., Lee, J.-Y., Podsakoff, N. P. (2003) "Common Method Biases in Behavioral Research: A Critical Review of the Literature and Recommended Remedies", Journal of Applied Psychology, 88(5), pp. 879-903. https://doi.org/10.1037/0021-9010.88.5.879 
Porter, M. E. (1985) "The Competitive Advantage: Creating and Sustaining Superior Performance", Free Press, New York, USA.

Sarstedt, M., Ringle, C. M., Smith, D., Reams, R., Hair Jr., J. F. (2014) "Partial Least Squares Structural Equation Modeling (PLS-SEM): A Useful Tool for Family Business Researchers", Journal of Family Business Strategy, 5(1), pp. 105-115.

https://doi.org/10.1016/j.jfbs.2014.01.002

Sousa, C. M. P., Martínez-López, F. J., Coelho, F. (2008) "The Determinants of Export Performance: A Review of the Research in the Literature Between 1998 and 2005", International Journal of Management Reviews, 10(4), pp. 343-374. https://doi.org/10.1111/j.1468-2370.2008.00232.x

Stouraitis, V., Harun, M. H. M., Kyritsis, M. (2017) "Motivators of SME initial export choice and the European Union regional effect in manufacturing", International Journal of Entrepreneurial Behavior \& Research, 23(1), pp. 35-55.

https://doi.org/10.1108/IJEBR-05-2015-0120

Teece, D. J., Pisano, G., Shuen, A. (1997) "Dynamic Capabilities and Strategic Management", Strategic Management Journal, 18(7), pp. 509-533.

https://doi.org/10.1002/(SICI)1097-0266(199708)18:7<509::AIDSMJ882>3.0.CO;2-Z
Wang, C. L., Ahmed, P. K. (2007) "Dynamic Capabilities: A Review and Research Agenda", International Journal of Management Reviews, 9(1), pp. 31-51.

https://doi.org/10.1111/j.1468-2370.2007.00201.x

Zahra, S. A., Garvis, D. M. (2000) "International corporate entrepreneurship and firm performance: The moderating effect of international environmental hostility", Journal of Business Venturing, 15(5-6), pp. 469-492.

https://doi.org/10.1016/S0883-9026(99)00036-1

Zahra, S. A., George, G. (2002) "Absorptive Capacity: A Review, Reconceptualization, and Extension", Academy of Management Review, 27(2), pp. 185-203. https://oi.org/10.2307/4134351

Zucchella, A., Siano, A. (2014) "Internationalization and Innovation as Resources for SME Growth in Foreign Markets: A Focus on Textile and Clothing Firms in the Campania Region", International Studies of Management and Organization, 44(1), pp. 21-41. https://doi.org/10.2753/IMO0020-8825440102 